\title{
MULTICRITERIA EVALUATION OF LITHUANIAN BANKS FROM THE PERSPECTIVE OF THEIR RELIABILITY FOR CLIENTS
}

\author{
Romualdas Ginevičius ${ }^{1}$, Valentinas Podvezko ${ }^{2}$ \\ Vilnius Gediminas Technical University, \\ Saulètekio al. 11, LT-10223 Vilnius, Lithuania \\ E-mails: ${ }^{1}$ romualdas.ginevicius@adm.vgtu.lt; ${ }^{2}$ valentinas.podvezko@fm.vgtu.lt \\ Received 29 October 2007; accepted 30 July 2008
}

\begin{abstract}
In recent years, efforts have been made to rank banks according to their reliability. However, the methods used for this purpose are not accurate. The analysis shows that reliability of banks is a complex phenomenon which can only be described by a set of criteria. The task is complicated by the fact that the criteria used have various dimensions as well as being oppositely directed. To solve the above problems, multicriteria evaluation methods, allowing the values of all the criteria of different dimensions and changeability to be integrated into a single generalized quantity, may be used.
\end{abstract}

Keywords: bank reliability, multicriteria evaluation methods.

\section{Introduction}

About half a year ago, Lithuanian banks were ranked according to their reliability (Kučinskaite, Putelytė 2007). The first attempt to do it was made three years ago (Putelyte 2004). These investigations differed in the number of the evaluation criteria used. In the first case, three main criteria (the most favourable terms of crediting the purchase of the property and availability of relevant information on the bank's website or over the telephone) were used. The second investigation was more exhaustive because it involved much more criteria significant for the clients.

The present investigation aimed at ranking Lithuanian banks is based on some particular methods. All the criteria are scored a particular number of points, depending on their significance. Less important criteria are given 5 points, while more important get 10 points. The total rank is obtained by integrating the points obtained from a particular bank (see Table 1).

In making the present investigation, valuable and comprehensive information about the performance of Lithuanian banks has been collected, allowing the authors to solve the problem of banks' ranking by applying advanced mathematical methods (Hwang, Yoon 1981; Figueira et al. 2005; Ustinovichius et al. 2007). The object of investigation - establishing of the banks' ranks, is a complex process which can be analysed only by investigating and evaluating the criteria describing their various facets. The problem is complicated by the fact that these criteria may have various dimensions and their values may change in opposite directions, implying that, in one case, a better situation may be indicated by the increase of some of the criteria values, while, in the other case, it is shown by the decrease of the criteria values. This makes the integration of these values into a single generalizing quantity much more difficult.

To solve the above problems, multicriteria evaluation methods, allowing us not only to reduce these multidimensional criteria to a common denominator but also to determine their significances with respect to the object considered, may be successfully used.

The present paper aims to perform multicriteria evaluation of reliability of Lithuanian banks and to compare 


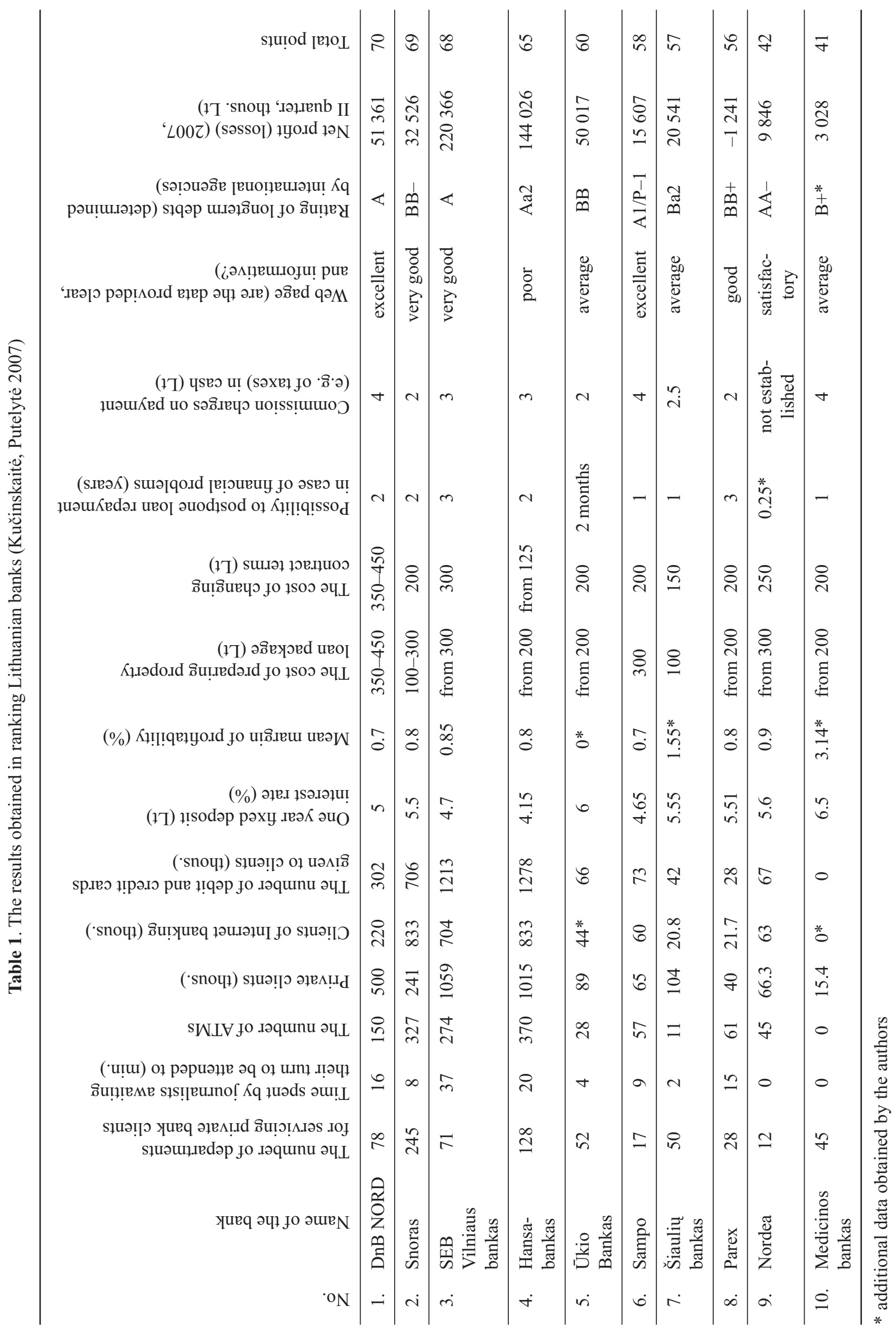


the results obtained with the data provided in the earlier performed ranking (Kučinskaite, Putelytė 2007). This is relevant because the literature on the problem of evaluating banks' performance deals only with some specific aspects of this process (Jasienè, Čapskas 2008). It should be noted that the analysis was made in November 2007, and it is evident that the values of some criteria have changed since that time. Therefore, now, the ranks of the banks may be also slightly different. However, the goal of the paper is to offer methodology for evaluating banks' reliability which could be used for making calculations based on scientifically grounded methods, when required.

\section{The criteria describing the reliability of Lithuanian banks}

In the present research, multicriteria evaluation of Lithuanian banks is based on the data provided in the previous investigation (see Table 1). Some data, however, were missing. For example, no information was given about the number of e-banking clients (in "Ūkio bankas" and "Medicinos bankas") and the mean margin of property loan interest (in "Ūkio bankas", "Šiaulių bankas", "Medicinos bankas") and about a possibility to postpone loan repayment in case of financial problems (in "Nordea" bank), as well as the rating of long-term debts determined by international agencies (in "Medicinos bankas"). These additional data were obtained by the authors who either called to the respective banks or spoke to bank employees to get the information. As shown in Table 1, the criteria have various dimensions, e.g. units, minutes, litas, percent, etc. Some of the criteria are maximizing, while others are minimizing. It implies that, in the first case, the situation is better, when the criteria values are increasing, while, in the second case, the situation is better, when the criteria values are decreasing (e.g. for the time of awaiting one's turn to be attended to). Moreover, some criteria have no numerical expression (e.g. rating of long-term debts, quality of the bank's website, etc.). Therefore, all the criteria were revised and their values were transformed to make them suitable for further calculation.

\section{Description of the criteria}

Criterion 1 is the number of departments for servicing individual clients. This is a maximizing criterion, implying that the more departments there are, the better the situation is. The availability of departments for servicing individual clients is very important for peo- ple living far from the regional centres because they can get bank services without going to these centres.

Criterion 2 is the time of awaiting one's turn to be attended to. The shorter the time, the better. Therefore, this criterion is minimizing, implying that the smaller the value of this criterion, the better the quality of servicing and the situation in the bank in this respect.

In many cases of multicriteria evaluation, the minimum criterion value cannot be equal to zero.

The values may be converted to positive values by the formula (Ginevičius, Podvezko 2007a):

$$
r_{i j}^{\prime}=r_{i j}+1
$$

where: $r_{i j}$ is the value of $i$-th criterion; $r_{i j}^{\prime}$ is rearranged $i$-th criterion value for $j$-th object.

In using some multicriteria evaluation methods, minimizing criteria should be transformed to maximizing ones. This may be made by the formula (Hwang, Yoon 1981; Ginevičius 2008; Ginevičius, Podvezko 2007a):

$$
\tilde{r}_{i j}=\frac{\min _{j} r_{i j}}{r_{i j}},
$$

where: $\tilde{r}_{i j}$ is maximized $i$-th criterion value; min $r_{i j}$ is the smallest $i$-th criterion value $\left(\min _{j} r_{i j}>0\right)$.

Criterion 3 is the number of ATMs (Automated Teller Machines) of the bank. Some banks have no ATMs. For this reason, they make agreements with other banks, and their clients can use ATMs of these banks to get cash. However, since they are not their clients, this operation is more expensive for them. Taking into account the fact that the banks not possessing ATMs still have the opportunity to encash their money, these banks were not excluded from calculations based on this criterion.

Criterion 4 is the number of individual clients. This criterion is maximizing and does not need to be transformed.

Criterion 5 is the number of bank clients in the Internet. This is also a maximizing criterion.

Criterion 6 is the number of credit and debit cards distributed by a bank to its clients. The criterion is better, when more cards are given to the clients, therefore, it should not be transformed either. However, some banks have not issued any credit and debit cards. In this case, zero criterion value was given to them. 
Criterion 7 is the interest rate for one-year deposit. This criterion is of special importance in the time of growing inflation, when the offered interest rate should be such as to protect the client's money from depreciation. This criterion is also maximizing.

Criterion 8 is the mean margin of property loan interest. When the economic and financial state is worsening, banks, usually, do not try to attract more clients for getting property loans because it is more difficult to foresee how many of the clients could become insolvent. Though the situation is unfavourable, the clients are still interested in getting loans at the lowest interest rate. Therefore, this criterion is minimizing. Its value should be maximized, i.e. transformed by the formula (2). Zero values of the criterion remain unchanged.

Criterion 9 defines the cost of preparing property loan package. The smaller the cost, the better, therefore, this criterion is minimizing. Banks have different approaches to determining this cost. Some of them give the true cost, while others define only the lower limit. This may be considered a drawback and a sort of trick. Taking into account this situation, the data presented in the journal "Veidas" were rearranged as follows: the true cost remained unchanged, while in the case, when the lower and upper limits were given, the upper limit was taken. In this case, when only the lower limit was indicated, the upper limit, the highest for all banks, was taken for calculations. The data were transformed by using the formula (2).

Criterion 10 is the cost of changing the contract terms. The situation in this case is similar to that of the criterion 9 , therefore, the same operations were made with the values of this criterion.

Criterion 11 shows the possibility to postpone repayment of the loan if the client was faced with financial problems. The longer the time of repayment, the better the situation. Therefore, this criterion is maximizing.

Criterion 12 denotes the charges on payments (e.g. taxes, etc.) in cash. The smaller the charges, the better the situation. Therefore, this criterion is minimizing. Quantitative evaluation of this criterion is complicated because some banks refuse to accept tax payments in cash. Considering this as a drawback, zero value was given to this criterion of the above banks. Other values were converted to maximizing by the formula (2). Zero values of the criterion remained unchanged.

Criterion 13 describes the quality of the bank's website. In the survey presented in the journal 'Veidas' only qualitative description of this criterion is provided, e.g. excellent, good, satisfactory, etc. In quantitative evalu- ation of the banks and their ranking, these estimates should be converted into the numerical ones. This was made in the following way (see Table 2):

Table 2. Quantitative evaluation of the quality of banks' websites

\begin{tabular}{|c|c|c|c|c|c|c|}
\hline $\begin{array}{l}\text { Qualitative evaluation } \\
\text { of bank's website }\end{array}$ & 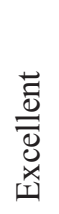 & $\begin{array}{l}\overrightarrow{8} \\
8 \\
0 \\
0 \\
\overrightarrow{0}\end{array}$ & $\begin{array}{l}\text { Z } \\
8 \\
\circlearrowleft\end{array}$ & 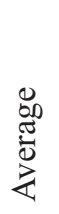 & 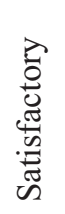 & 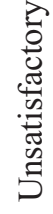 \\
\hline $\begin{array}{l}\text { Quantitative evaluation } \\
\text { of bank's website }\end{array}$ & 6 & 5 & 4 & 3 & 2 & 1 \\
\hline
\end{tabular}

The higher the quality of the site, the higher the estimate. Therefore, this criterion is maximizing.

Criterion 14 presents the rating of long-term debts determined by international agencies, such as "Moody 's", "Fitch Ratings", "Standard\&Poor". In general, it shows bank's capability to respond to liabilities when the number of insolvent clients has grown. Long-term debts are indicated by the levels denoted by the respective symbols (Table 3 ).

The higher the estimate, the larger its numerical value, therefore, this criterion is also maximizing.

The results obtained in ranking Lithuanian banks are presented in Table 1. To use these data as a set of criteria describing bank reliability, they should be expressed quantitatively. To achieve this, the lowest rank should be assigned the smallest number of points, while the highest value should be given the largest point number.

Criterion 15 is net bank profit (loss) in the second quarter of 2007. To find a quantitative expression for this criterion was rather complicated because some banks were unprofitable. To keep these banks in the analysis (ranking), negative criteria values were made positive according to the formula (Ginevičius, Podvezko 2007a):

$$
r_{i j}^{*}=\left|\min _{j} r_{i j}\right|+r_{i j}+1,
$$

where: $r_{i j}^{*}$ is rearranged net profit (losses) of $i$-th criterion for $j$-th object; $\min _{j} r_{i j}$ is the smallest value of $i$-th criterion.

The higher the profit, the better the situation, therefore, this criterion is maximizing.

Rearranged values of all the criteria are given in Table 4 . 
Table 3. Evaluation of banks based on long-term debts according to international agencies' rating

\begin{tabular}{|c|c|c|c|c|}
\hline \multicolumn{3}{|c|}{ Evaluation symbols used by international agencies } & \multirow[t]{2}{*}{ Symbol's meaning } & \multirow{2}{*}{$\begin{array}{l}\text { The suggested scoring } \\
\text { (points) }\end{array}$} \\
\hline Moody`s & $\mathrm{S} \& \mathrm{P}$ & Fitch Ratings & & \\
\hline Aaa & AAA & AAA & The highest level of safety & 24 \\
\hline Aal & $\mathrm{AA}+$ & $\mathrm{AA}+$ & \multirow{3}{*}{ High level of safety } & 23 \\
\hline $\mathrm{Aa} 2$ & AA & AA & & 22 \\
\hline Aa3 & $\mathrm{AA}-$ & $\mathrm{AA}-$ & & 21 \\
\hline A1 & $\mathrm{A}+$ & $\mathrm{A}+$ & \multirow{3}{*}{ Higher investment rating } & 20 \\
\hline $\mathrm{A} 2$ & $\mathrm{~A}$ & $\mathrm{~A}$ & & 19 \\
\hline A3 & $\mathrm{A}-$ & A- & & 18 \\
\hline Baa1 & $\mathrm{BBB}+$ & $\mathrm{BBB}+$ & \multirow{3}{*}{ Lower investment rating } & 17 \\
\hline Baa2 & $\mathrm{BBB}$ & BBB & & 16 \\
\hline Baa3 & BBB- & BBB- & & 15 \\
\hline Bal & $\mathrm{BB}+$ & $\mathrm{BB}+$ & \multirow{3}{*}{ Non-investment (speculation) rating } & 14 \\
\hline $\mathrm{Ba} 2$ & $\mathrm{BB}$ & $\mathrm{BB}$ & & 13 \\
\hline $\mathrm{Ba} 3$ & $\mathrm{BB}-$ & $\mathrm{BB}-$ & & 12 \\
\hline $\mathrm{B} 1$ & $\mathrm{~B}+$ & $\mathrm{B}+$ & \multirow{3}{*}{ High speculation rating } & 11 \\
\hline $\mathrm{B} 2$ & $\mathrm{~B}$ & $\mathrm{~B}$ & & 10 \\
\hline B3 & B- & $\mathrm{B}-$ & & 9 \\
\hline Caa1 & $\mathrm{CCC}+$ & $\mathrm{CCC}$ & \multirow{3}{*}{ Poor state } & 8 \\
\hline Caa2 & $\mathrm{CCC}$ & - & & 7 \\
\hline $\mathrm{Caa} 3$ & $\mathrm{CCC}-$ & - & & 6 \\
\hline $\mathrm{Ca}$ & $\mathrm{CC}$ & $\mathrm{CC}$ & Particularly high speculation rating & 5 \\
\hline $\mathrm{C}$ & $\mathrm{C}$ & $\mathrm{C}$ & Potential failure to meet liabilities & 4 \\
\hline- & - & DDD & \multirow{3}{*}{ Failure to meet liabilities } & 3 \\
\hline- & - & DD & & 2 \\
\hline- & $\mathrm{D}$ & $\mathrm{D}$ & & 1 \\
\hline
\end{tabular}

Table 4. Rearranged data on the commercial banks of Lithuania for 2007

\begin{tabular}{|c|c|c|c|c|c|c|c|c|c|c|c|}
\hline \multirow{2}{*}{$\begin{array}{c}\text { Criterion } \\
\text { No. }\end{array}$} & \multirow{2}{*}{$\begin{array}{l}\text { Type of } \\
\text { criterion }\end{array}$} & \multicolumn{10}{|c|}{ Banks } \\
\hline & & 1 & 2 & 3 & 4 & 5 & 6 & 7 & 8 & 9 & 10 \\
\hline 1 & $+*$ & 78 & 245 & 71 & 128 & 52 & 17 & 50 & 20 & 12 & 45 \\
\hline 2 & $-* *$ & 17 & 9 & 38 & 21 & 5 & 10 & 3 & 16 & 1 & 1 \\
\hline 3 & + & 150 & 327 & 274 & 370 & 28 & 57 & 11 & 61 & 45 & 0 \\
\hline 4 & + & 500 & 241 & 1059 & 1015 & 89 & 65 & 104 & 40 & 66.3 & 15.4 \\
\hline 5 & + & 220 & 833 & 704 & 833 & 44 & 60 & 20.8 & 21.7 & 63 & 4 \\
\hline 6 & + & 302 & 706 & 1213 & 1278 & 66 & 73 & 42 & 28 & 67 & 0 \\
\hline 7 & + & 5.0 & 5.5 & 4.7 & 4.15 & 6.0 & 4.65 & 5.55 & 5.51 & 5.6 & 6.5 \\
\hline 8 & + & 1 & 0.875 & 0.8235 & 0.875 & 0 & 1 & 0.4516 & 0.875 & 0.778 & 0.113 \\
\hline 9 & - & 450 & 300 & 450 & 450 & 450 & 300 & 100 & 450 & 450 & 450 \\
\hline 10 & - & 450 & 200 & 300 & 450 & 200 & 200 & 150 & 200 & 250 & 200 \\
\hline 11 & + & 2 & 2 & 3 & 2 & 0.17 & 1 & 1 & 3 & 0.25 & 1 \\
\hline 12 & + & 0.5 & 1 & 0.6667 & 0.6667 & 1 & 0.5 & 0.8 & 1 & 0 & 0.5 \\
\hline 13 & + & 6 & 5 & 5 & 1 & 3 & 6 & 3 & 4 & 2 & 3 \\
\hline 14 & + & 19 & 12 & 19 & 22 & 13 & 20 & 13 & 14 & 21 & 9 \\
\hline 15 & + & 52603 & 33768 & 221608 & 145268 & 51258 & 16849 & 21783 & 1 & 11088 & 4270 \\
\hline
\end{tabular}




\section{Multicriteria methods used for determining the reliability of banks}

Multicriteria methods are based on two matrices: a matrix of the criteria describing the banks considered, statistical data or expert estimates $\mathbf{R}=\left\|r_{i j}\right\|$, and weight (significance) vector of the criteria $\Omega=\left\|\omega_{i}\right\|(i=$ $1, \ldots, m ; j=1, \ldots, n)$, where $m$ is the number of criteria and $n$ is the number of the objects (banks) compared. Multicriteria evaluation methods are used for ranking the banks according to their reliability.

The data on the commercial banks of Lithuania for 2007 (matrix R) are given in Table 4. The type of criteria (maximizing '+' or minimizing '-') is indicated in column 2 .

In the present investigation, four multicriteria evaluation methods, such as $S R$ (sum of ranks), $S A W$ (Simple Additive Weighting), TOPSIS (Technique for Order Preference by Similarity to an Ideal Solution) and COPRAS (Complex Proportional Assessment) were used.

The criterion $V_{j}$ of the $S R$ method was calculated by the formula (Ginevičius, Podvezko 2004, 2006, 2008a):

$$
V_{j}=\sum_{i=1}^{m} m_{i j}
$$

where: $m_{i j}$ is $i$-th criterion rank for $j$-th object. The best value of the criterion $V_{j}$ is the smallest value.

The main concept of quantitative multicriteria methods is clearly demonstrated by the method SAW (Hwang,
Yoon 1981; Ginevičius, Podvezko 2008b; Ginevičius et al. 2006, 2008; Shevchenko et al. 2008). The criterion $S_{j}$ of this method is the sum of the weighted criteria values:

$$
S_{j}=\sum_{i=1}^{m} \omega_{i} \tilde{r}_{i j},
$$

where: $\omega_{i}$ is the weight of $i$-th criterion; $\tilde{r}_{i j}$ is normalized $i$-th criterion value for $j$-th object.

$S A W$ is based on 'classical' normalization (Ginevičius, Podvezko 2007b):

$$
\begin{aligned}
& \tilde{r}_{i j}=\frac{r_{i j}}{\sum_{j=1}^{n} r_{i j}} \\
& \left(i=1, \ldots, m ; j=1, \ldots, n ; \sum_{j=1}^{n} \tilde{r}_{i j}=1\right) .
\end{aligned}
$$

The data on the commercial banks of Lithuania for 2007 normalized by the method SAW are given in Table 5 .

The best value of the criterion $S_{j}$ is the largest value.

The method TOPSIS is based on vector normalization (Hwang, Yoon 1981; Opricovic, Tzeng 2004; Zavadskas et al. 2006):

$$
\begin{aligned}
& \tilde{r}_{i j}=\frac{r_{i j}}{\sqrt{\sum_{j=1}^{n} r_{i j}^{2}}} \\
& (i=1, \ldots, m ; j=1, \ldots, n),
\end{aligned}
$$

\begin{tabular}{|c|c|c|c|c|c|c|c|c|c|c|}
\hline \multirow[t]{2}{*}{ Criterion } & \multicolumn{10}{|c|}{ Banks } \\
\hline & 1 & 2 & 3 & 4 & 5 & 6 & 7 & 8 & 9 & 10 \\
\hline 1 & 0.1086 & 0.3412 & 0.0989 & 0.1783 & 0.0724 & 0.0237 & 0.0696 & 0.0279 & 0.0167 & 0.0627 \\
\hline 2 & 0.0200 & 0.0378 & 0.0090 & 0.0162 & 0.0580 & 0.0340 & 0.1134 & 0.0213 & 0.3402 & 0.3402 \\
\hline 3 & 0.1134 & 0.2472 & 0.2071 & 0.2797 & 0.0212 & 0.0431 & 0.0083 & 0.0461 & 0.0340 & 0.0000 \\
\hline 4 & 0.1565 & 0.0754 & 0.3315 & 0.3177 & 0.0279 & 0.0203 & 0.0326 & 0.0125 & 0.0208 & 0.0048 \\
\hline 5 & 0.0785 & 0.2971 & 0.2511 & 0.2971 & 0.0157 & 0.0214 & 0.0074 & 0.0077 & 0.0225 & 0.0014 \\
\hline 6 & 0.0800 & 0.1870 & 0.3213 & 0.3385 & 0.0175 & 0.0193 & 0.0111 & 0.0074 & 0.0177 & 0.0000 \\
\hline 7 & 0.0941 & 0.1035 & 0.0884 & 0.0781 & 0.1129 & 0.0875 & 0.1044 & 0.1036 & 0.1053 & 0.1223 \\
\hline 8 & 0.1473 & 0.1288 & 0.1213 & 0.1288 & 0.0000 & 0.1473 & 0.0665 & 0.1288 & 0.1146 & 0.0166 \\
\hline 9 & 0.0690 & 0.1034 & 0.0690 & 0.0690 & 0.0690 & 0.1034 & 0.3103 & 0.0690 & 0.0690 & 0.0690 \\
\hline 10 & 0.0512 & 0.1151 & 0.0767 & 0.0512 & 0.1151 & 0.1151 & 0.1535 & 0.1151 & 0.0921 & 0.1151 \\
\hline 11 & 0.1297 & 0.1297 & 0.1946 & 0.1297 & 0.0110 & 0.0649 & 0.0648 & 0.1946 & 0.0162 & 0.0649 \\
\hline 12 & 0.0754 & 0.1508 & 0.1005 & 0.1005 & 0.1508 & 0.0754 & 0.1206 & 0.1508 & 0.0000 & 0.0754 \\
\hline 13 & 0.1579 & 0.1316 & 0.1316 & 0.0263 & 0.0789 & 0.1579 & 0.0789 & 0.1053 & 0.0526 & 0.0789 \\
\hline 14 & 0.1173 & 0.0741 & 0.1173 & 0.1358 & 0.0802 & 0.1235 & 0.0802 & 0.0864 & 0.1296 & 0.0556 \\
\hline 15 & 0.0942 & 0.0605 & 0.3968 & 0.2601 & 0.0918 & 0.0302 & 0.0390 & 0.0000 & 0.0199 & 0.0076 \\
\hline
\end{tabular}

where $\tilde{r}_{i j}$ is normalized value of $i$-th criterion for $j$-th object.

Table 5. The data on the commercial banks of Lithuania for 2007 normalized by the method SAW 
The best variant (solution) $V^{*}$ and the worst variant $V^{-}$are calculated by the formulas:

$$
\begin{aligned}
& V^{*}=\left\{V_{1}^{*}, V_{2}^{*}, \ldots, V_{m}^{*}\right\}= \\
& \left\{\left(\max _{j} \omega_{i} \tilde{r}_{i j} / i \in I_{1}\right),\left(\min _{j} \omega_{i} \tilde{r}_{i j} / i \in I_{2}\right)\right\}, \\
& V^{-}=\left\{V_{1}^{-}, V_{2}^{-}, \ldots, V_{m}^{-}\right\}= \\
& \left\{\left(\min _{j} \omega_{i} \tilde{r}_{i j} / i \in I_{1}\right),\left(\max _{j} \omega_{i} \tilde{r}_{i j} / i \in I_{2}\right)\right\},
\end{aligned}
$$

where: $I_{1}$ is a set of indices of maximized criteria, $I_{2}$ is a set of indices of minimized criteria.

The distance $D_{j}^{*}$ of every considered variant to the ideal (best) solutions and its distance $D_{j}^{-}$to the worst solutions are calculated by the formulas:

$$
\begin{aligned}
& D_{j}^{*}=\sqrt{\sum_{i=1}^{m}\left(\omega_{i} \tilde{r}_{i j}-V_{i}^{*}\right)^{2},} \\
& D_{j}^{-}=\sqrt{\sum_{i=1}^{m}\left(\omega_{i} \tilde{r}_{i j}-V_{i}^{-}\right)^{2}} .
\end{aligned}
$$

The criterion $C_{j}^{*}$ of the method TOPSIS is calculated by the formula:

$$
\begin{aligned}
& C_{j}^{*}=\frac{D_{j}^{-}}{D_{j}^{*}+D_{j}^{-}}(j=1, \ldots, n) \\
& \left(0 \leq C_{j}^{*} \leq 1\right) .
\end{aligned}
$$

The largest value of the criterion $C_{j}^{*}$ corresponds to the best variant.

The criterion $Z_{j}$ of the method COPRAS is calculated by the formula (Kaklauskas et al. 2006, 2007; Zavadskas, Kaklauskas 2007; Zavadskas et al. 2007; Zavadskas, Antucheviciene 2007; Viteikiene, Zavadskas 2007):

$$
Z_{j}=S_{+j}+\frac{S_{-\min } \sum_{j=1}^{n} S_{-j}}{S_{-j} \sum_{j=1}^{n} \frac{S_{-\min }}{S_{-j}}},
$$

where: $S_{+j}=\sum_{i=1}^{m} \omega_{i} \tilde{r}_{+i j}$ is the sum of the weighted values of maximizing criteria $\tilde{r}_{+i j}, S_{-j}=\sum_{i=1}^{m} \omega_{i} \tilde{r}_{-i j}$ is same for minimizing criteria (their minimum value $S_{-\min }=\min _{j} S_{-j}$ ).

Calculating the values of the criterion $Z_{j}$, a method of normalization of the initial data based on the use of formula (6) was applied.

Below, basic components of multicriteria methods are discussed in detail.

\section{Determining the criteria weights and the agreement of expert estimates}

One of two components of multicriteria evaluation methods is represented by the values of the criteria weights (significances) $\omega_{i}$.

The effect of particular criteria describing the investigated object on the result obtained differs to some extent, therefore, when using quantitative multicriteria evaluation methods, the criteria weights (significances) should be determined. The so-called subjective multicriteria evaluation is often used, when experts determine the criteria weights. However, objective estimates are also obtained (Ustinovičius, Zavadskas 2004; Ginevičius 2006; Zavadskas et al. 2006).

The expert evaluation method yields a matrix $\mathrm{C}=\left\|c_{i k}\right\|$ $(i=1, \ldots, m ; k=1, \ldots, r)$, where $m$ is the number of the criteria considered, $r$ is the number of experts. Experts can assess the criteria in various ways. Any scale of measurement may be used, e.g. units, percentage, fraction of unity, various scoring systems based on points, simple (0-1) pairwise comparison of criteria (Zavadskas, Kaklauskas 2007), as well as the scale of Saaty's analytical hierarchical process (AHP) (Saaty 1980, 2005; Ginevičius et al. 2008; Su et al. 2006), etc.

When the method of direct determination of the criteria weights is used, the sum of the weights elicited from each expert should be equal to unity (or $100 \%$ ). In this case, the weight of the $i$-th criterion $\omega_{i}$ is the mean value of all experts' estimates $\bar{c}_{i}$ :

$$
\omega_{i}=\bar{c}_{i}=\frac{\sum_{k=1}^{r} c_{i k}}{r} .
$$

In the case of percentage, the obtained value is divided by 100 .

In the present investigation, experts used a direct method of criteria evaluation, i.e. the sum of the estimates of any expert was equal to 100 . The estimates of 15 criteria elicited from 9 experts are given in Table 6. In the last columns of the table, the sums of the estimates of each criterion elicited from all experts, as well as the criteria weights and ranks are provided.

We can see that expert estimates and approaches to criteria evaluation differ. It is hardly possible to determine if expert estimates are in agreement based on the data presented in Table 6 . To use the calculated criteria weights $\omega_{1}$ in multicriteria evaluation of banks, the level of agreement of experts' estimates should be determined. For this purpose, the concordance coefficient $W$ (Kendall 1970; Podvezko 2007; Viteikienè 2006) is applied. 
Table 6. Direct evaluation of the criteria weights (significances) by experts

\begin{tabular}{|c|c|c|c|c|c|c|c|c|c|c|c|c|}
\hline \multirow[t]{2}{*}{ Criteria } & \multicolumn{9}{|c|}{ Experts } & \multirow[t]{2}{*}{ Total } & \multirow[t]{2}{*}{ Weight } & \multirow[t]{2}{*}{ Rank } \\
\hline & 1 & 2 & 3 & 4 & 5 & 6 & 7 & 8 & 9 & & & \\
\hline 1 & 10 & 10 & 7 & 3 & 9 & 5 & 5 & 12 & 5 & 66 & 0.0733 & 7 \\
\hline 2 & 4 & 9 & 5 & 3 & 7 & 10 & 5 & 15 & 5 & 63 & 0.0700 & 8 \\
\hline 3 & 7 & 8 & 5 & 10 & 6 & 5 & 5 & 7 & 5 & 58 & 0.0644 & 9 \\
\hline 4 & 7 & 3 & 3 & 6 & 5 & 1 & 10 & 7 & 15 & 57 & 0.0633 & 10 \\
\hline 5 & 7 & 3 & 10 & 12 & 10 & 10 & 10 & 5 & 10 & 77 & 0.0856 & $2-3$ \\
\hline 6 & 7 & 3 & 3 & 3 & 3 & 2 & 10 & 4 & 7 & 42 & 0.0467 & 13 \\
\hline 7 & 2 & 10 & 10 & 10 & 6 & 10 & 8 & 13 & 5 & 74 & 0.0822 & $4-5$ \\
\hline 8 & 5 & 10 & 10 & 6 & 12 & 15 & 8 & 8 & 5 & 79 & 0.0878 & 1 \\
\hline 9 & 2 & 7 & 5 & 6 & 4 & 7 & 1 & 3 & 2 & 37 & 0.0411 & 14 \\
\hline 10 & 3 & 7 & 5 & 6 & 2 & 8 & 1 & 2 & 2 & 36 & 0.0400 & 15 \\
\hline 11 & 1 & 8 & 5 & 6 & 8 & 9 & 1 & 2 & 7 & 47 & 0.0522 & 11 \\
\hline 12 & 4 & 8 & 7 & 3 & 3 & 6 & 1 & 12 & 2 & 46 & 0.0511 & 12 \\
\hline 13 & 8 & 7 & 5 & 12 & 14 & 5 & 13 & 6 & 7 & 77 & 0.0856 & $2-3$ \\
\hline 14 & 15 & 4 & 10 & 10 & 7 & 3 & 11 & 1 & 13 & 74 & 0.0822 & $4-5$ \\
\hline 15 & 18 & 3 & 10 & 4 & 4 & 4 & 11 & 3 & 10 & 67 & 0.0744 & 6 \\
\hline Total & 100 & 100 & 100 & 100 & 100 & 100 & 100 & 100 & 100 & 100 & 1.00 & - \\
\hline
\end{tabular}

The calculation of the concordance coefficient is based on ranking of the criteria. Ranking is a procedure, when the most important criterion is assigned the rank equal to one. The second most important criterion is given the rank 2, etc., while the criterion which is the last according to its importance is given the rank $m$, where $m$ is the number of the criteria (objects). The equivalent criteria are assigned the same rank, i.e. an arithmetical mean of the respective ranks.
In fact, the level of the agreement of experts' estimates, i.e. the concordance coefficient, is determined by the criterion $\chi^{2}$, rather than by the value $W$. A random value

$$
\chi^{2}=W r(m-1)
$$

is distributed according to $\chi^{2}$ distribution with the degree of freedom $v=m-1$, where $m$ is the number of the objects compared and $r$ is the number of experts (Kendall 1970). Based on the selected significance

Table 7. Ranking of experts' criteria

\begin{tabular}{ccccccccccc}
\hline \multirow{2}{*}{ Criteria } & \multicolumn{7}{c}{ Experts } & \multirow{2}{*}{ Sum } \\
\cline { 2 - 9 } & 1 & 2 & 3 & 4 & 5 & 6 & 7 & 8 & 9 & \\
\hline 1 & 3 & 2 & 6.5 & 13.5 & 4 & 10 & 10 & 3.5 & 10 & 62.5 \\
\hline 2 & 10.5 & 4 & 10 & 13.5 & 6.5 & 3 & 10 & 1 & 10 & 68.5 \\
\hline 3 & 6.5 & 6 & 10 & 4 & 8.5 & 10 & 10 & 6.5 & 10 & 71.5 \\
\hline 4 & 6.5 & 13.5 & 14.5 & 8 & 10 & 15 & 5 & 6.5 & 1 & 80 \\
\hline 5 & 6.5 & 13.5 & 3 & 1.5 & 3 & 3 & 5 & 9 & 3.5 & 48 \\
\hline 6 & 6.5 & 13.5 & 14.5 & 13.5 & 13.5 & 14 & 5 & 10 & 6 & 96.5 \\
\hline 7 & 13.5 & 2 & 3 & 4 & 8.5 & 3 & 7.5 & 2 & 10 & 53.5 \\
\hline 8 & 9 & 2 & 3 & 8 & 2 & 1 & 7.5 & 5 & 10 & 47.5 \\
\hline 9 & 13.5 & 9 & 10 & 8 & 11.5 & 7 & 13.5 & 11.5 & 14 & 98 \\
\hline 10 & 12 & 9 & 10 & 8 & 15 & 6 & 13.5 & 13.5 & 14 & 101 \\
\hline 11 & 15 & 6 & 10 & 8 & 5 & 5 & 13.5 & 13.5 & 6 & 82 \\
\hline 12 & 10.5 & 6 & 6.5 & 13.5 & 13.5 & 8 & 13.5 & 3.5 & 14 & 89 \\
\hline 13 & 4 & 9 & 10 & 1.5 & 1 & 10 & 1 & 8 & 6 & 50.5 \\
\hline 14 & 2 & 11 & 3 & 4 & 6.5 & 13 & 2.5 & 15 & 2 & 59 \\
\hline 15 & 1 & 13.5 & 3 & 11 & 11.5 & 12 & 2.5 & 11.5 & 3.5 & 69.5 \\
\hline Total & 120 & 120 & 120 & 120 & 120 & 120 & 120 & 120 & 120 & 1080 \\
\hline
\end{tabular}


level $\alpha$ (in practice, $\alpha$ is usually equal to 0.05 or 0.01 ), the critical value $\chi_{k r}^{2}$ is found in the table of $\chi^{2}$ distribution with the degree of freedom $v=m-1$. If the value of $\chi^{2}$ calculated from the formula (15) is larger than $\chi_{k r}^{2}$, then, it is assumed that experts' estimates are in agreement (Kendall 1970; Zavadskas, Kaklauskas 2007; Podvezko 2007; Turskis et al. 2006).

The data obtained by direct evaluation of the criteria weights by experts (Table 6) can be easily rearranged into the ranking table. The results of ranking are given in Table 7.

Concordance coefficient is $W=0.213$, and the value of $\chi^{2}$ calculated by formula (15), $\chi^{2}=26.82$, is larger than the critical value $\chi_{k r}^{2}=23.685$, taken from the table of $\chi^{2}$ distribution with the degree of freedom $v=15-1=14$ and the significance level $\alpha=0.05$. Therefore, the experts' estimates are in agreement. In Table 7, different criteria have the same ranks assigned by the experts. Such ranks are referred to as tied ranks. If tied ranks are taken into account (Kendall 1970; Podvezko 2006, 2007), the values of $W$ and $\chi^{2}$ will even be larger, accordingly increasing the agreement level of experts' estimates.

The calculated criteria weights $\omega_{i}$, revised in the manner described above, may be used in multicriteria evaluation of banks.

\section{Multicriteria evaluation of Lithuanian banks}

The ranks assigned to Lithuanian banks based on particular criteria which were determined by formula (4) are presented in Table 8 .

The data obtained in multicriteria evaluation of Lithuanian banks by using formulas (4)-(13) are given in Table 9.

Based on the data presented in Table 9, a few conclusions can be drawn. One can see that evaluation (ranking) results obtained by using multicriteria methods differ considerably from those reported in other investigations (Kučinskaite, Putelyte 2007). The calculations made in the present work show that all banks ranked according to their reliability on the date indicated can be divided into three groupings. The first group includes SEB "Vilniaus bankas", "Hansabankas" and "Snoras". The second group includes the bank "DnB NORD" and the third group embraces all other banks of Lithuania.

Table 8. The ranks assigned to Lithuanian commercial banks according to their reliability in 2007

\begin{tabular}{|c|c|c|c|c|c|c|c|c|c|c|}
\hline \multirow[t]{2}{*}{ Criteria } & \multicolumn{10}{|c|}{ Banks } \\
\hline & 1 & 2 & 3 & 4 & 5 & 6 & 7 & 8 & 9 & 10 \\
\hline & 3 & 1 & 4 & 2 & 5 & 9 & 6 & 8 & 10 & 7 \\
\hline & 8 & 5 & 10 & 9 & 4 & 6 & 3 & 7 & 1.5 & 1.5 \\
\hline & 4 & 2 & 3 & 1 & 8 & 6 & 9 & 5 & 7 & 10 \\
\hline & 3 & 4 & 1 & 2 & 6 & 8 & 5 & 9 & 7 & 10 \\
\hline & 4 & 1.5 & 3 & 1.5 & 7 & 6 & 9 & 8 & 5 & 10 \\
\hline & 4 & 3 & 2 & 1 & 7 & 5 & 8 & 9 & 6 & 10 \\
\hline & 7 & 6 & 8 & 10 & 2 & 9 & 4 & 5 & 3 & 1 \\
\hline & 1.5 & 4 & 6 & 4 & 10 & 1.5 & 8 & 4 & 7 & 9 \\
\hline & 7 & 2.5 & 7 & 7 & 7 & 2.5 & 1 & 7 & 7 & 7 \\
\hline & 9.5 & 4 & 8 & 9.5 & 4 & 4 & 1 & 4 & 7 & 4 \\
\hline & 4 & 4 & 1.5 & 4 & 10 & 7 & 7 & 1.5 & 9 & 7 \\
\hline & 8 & 2 & 5.5 & 5,5 & 2 & 8 & 4 & 2 & 10 & 8 \\
\hline & 1.5 & 3.5 & 3.5 & 10 & 7 & 1.5 & 7 & 5 & 9 & 7 \\
\hline & 4.5 & 9 & 4.5 & 1 & 7.5 & 3 & 7.5 & 6 & 2 & 10 \\
\hline & 3 & 5 & 1 & 2 & 4 & 7 & 6 & 10 & 8 & 9 \\
\hline $\begin{array}{c}\text { Sum of } \\
\text { ranks }\end{array}$ & 72 & 56.5 & 68 & 69.5 & 90.5 & 83.5 & 85.5 & 90.5 & 98.5 & 110.5 \\
\hline Rank & 4 & 1 & 2 & 3 & $7-8$ & 5 & 6 & $7-8$ & 9 & 10 \\
\hline
\end{tabular}


Table 9. The results obtained in comparing the reliability of Lithuanian commercial banks by multicriteria methods

\begin{tabular}{|c|c|c|c|c|c|c|c|c|c|c|c|}
\hline \multicolumn{2}{|c|}{ Method } & \multicolumn{10}{|c|}{ Banks } \\
\hline & & 1 & 2 & 3 & 4 & 5 & 6 & 7 & 8 & 9 & 10 \\
\hline \multirow[t]{2}{*}{$S R$} & Value & 72 & 56.5 & 68 & 69.5 & 90.5 & 83.5 & 85.5 & 90.5 & 98.5 & 110.5 \\
\hline & Rank & 4 & 1 & 2 & 3 & $7-8$ & 5 & 6 & $7-8$ & 9 & 10 \\
\hline \multirow[t]{2}{*}{$S A W$} & Value & 0.1034 & 0.1475 & 0.1682 & 0.1609 & 0.0605 & 0.0730 & 0.0759 & 0.0695 & 0.0740 & 0.0699 \\
\hline & Rank & 4 & 3 & 1 & 2 & 10 & 7 & 5 & 9 & 6 & 8 \\
\hline \multirow[t]{2}{*}{ TOPSIS } & Value & 0.451 & 0.619 & 0.610 & 0.641 & 0.333 & 0.377 & 0.348 & 0.345 & 0.344 & 0.317 \\
\hline & Rank & 4 & 2 & 3 & 1 & 9 & 5 & 6 & 7 & 8 & 10 \\
\hline \multirow[t]{2}{*}{ COPRAS } & Value & 0.1052 & 0.1512 & 0.1673 & 0.1622 & 0.0646 & 0.0763 & 0.0833 & 0.0708 & 0.0626 & 0.0563 \\
\hline & Rank & 4 & 3 & 1 & 2 & 8 & 6 & 5 & 7 & 9 & 10 \\
\hline \multicolumn{2}{|c|}{ Sum of ranks } & 16 & 9 & 7 & 8 & 34.5 & 23 & 22 & 30,5 & 32 & 38 \\
\hline \multicolumn{2}{|c|}{ Total rank } & 4 & 3 & 1 & 2 & 9 & 6 & 5 & 7 & 8 & 10 \\
\hline \multicolumn{2}{|c|}{$\begin{array}{l}\text { Rank given by other } \\
\text { methods }\end{array}$} & 1 & 2 & 3 & 4 & 10 & 5 & 6 & 7 & 8 & 9 \\
\hline
\end{tabular}

\section{Conclusions}

One of the most important factors influencing the economic development of any state is effective performance and reliability of the banks. The reliability of banks is a complex phenomenon, described by a set of criteria, which have various dimensions and may be oppositely directed. The problems of this kind may be solved by using multicriteria evaluation methods allowing the integration of different criteria into a single generalizing quantity.

To perform quantitative multicriteria evaluation, the values of all the criteria should be rearranged in such a way that they could be used in calculations. In some cases, zero criteria values should be converted to nonzero values, while, in other cases, negative values should be made positive or their quantitative expression should be changed to qualitative, etc.

For multicriteria evaluation the values of the criteria as well as the criteria weights should be known. The criteria weights are determined by experts. Therefore, the agreement of experts' estimates should be checked.

Multicriteria evaluation of Lithuanian banks performed in the present investigation shows that the results obtained differ considerably from the data reported by other researchers using simpler and less accurate methods.

The research made allows the authors to divide all Lithuanian banks into three groups according to their reliability at the period considered. The first group includes SEB "Vilniaus bankas", "Hansabankas" and "Snoras", while the second group includes the bank "DnB NORD", and the third group embraces all other banks of Lithuania.

\section{References}

Figueira, J.; Greco, S.; Ehrgott, M. 2005. Multiple Criteria Decision Analysis: State of the Art Survey. Springer.

Ginevičius, R. 2006. Multicriteria evaluation of the criteria weights by multicriteria methods based on their interrelationships, Business: Theory and Practice 7(1): 3-13.

Ginevičius, R. 2008. Normalization of quantities of various dimensions, Journal of Business Economics and Management 9(1): 79-86.

Ginevičius, R.; Podvezko, V. 2004. Complex evaluation of the use of information technologies in the Countries of Eastern and Central Europe, Journal of Business Economics and Management 5(4): 183-191.

Ginevičius, R.; Podvezko, V. 2006. Assessing the Financial state of construction enterprises, Technological and Economic Development of Economy 12(3): 188-194.

Ginevičius, R.; Podvezko, V. 2007a. Some problems of evaluating multicriteria decision methods, International Journal of Management and Decision Making 8 (5/6): 527-539.

Ginevičius, R.; Podvezko, V. 2007b. Complex assessment of sustainable development of state regions with emphasis on ecological and dwelling conditions, Ekologija 53: 41-48.

Ginevičius, R.; Podvezko, V. 2008a. The problem of compatibility of various multiple criteria evaluation methods, Business: Theory and Practice 9(1): 73-80.

Ginevičius, R.; Podvezko, V. 2008b. A feasibility study of multicriteria methods' application to quantitative evaluation of social phenomena, Business: Theory and Practice 9(2): 81-87.

Ginevičius, R.; Butkevičius, A.; Podvezko, V. 2006. Complex evaluation of economic development of the Baltic states and Poland, Ekonomický Časopis [Journal of Economics] 54(9): 918-930. 
Ginevičius, R.; Podvezko, V.; Bruzgè, Š. 2008. Evaluating the effect of state aid to business by multicriteria methods, Journal of Business Economics and Management 9(3): 167-180.

Hwang, C.L.; Yoon, K. 1981. Multiple attribute decision making methods and applications. Berlin, Heidelberg, New York: Springer-Verlag.

Jasiene, M.; Čapskas, G. 2008. Rate of interest and the investigation of the essential influencing factors in Lithuania in 1994-2006, Business: Theory and Practice 9(1): 45-50.

Kaklauskas, A.; Zavadskas, E. K.; Banaitis, A.; Šatkauskas, G. 2007. Defining the utility and market value of real estate by a multiple criteria approach, International Journal of Strategic Property Management 11(2): 107-120.

Kaklauskas, A.; Zavadskas, E. K.; Raslanas, S.; Ginevičius, R.; Komka, A.; Malinauskas, P. 2006. Selection of low-e windows in retrofit of public buildings by applying multiple criteria method COPRAS: A Lithuanian case, Energy and Buildings 38: 454-462.

Kendal, M. 1970. Rank correlation methods. London: Griffin.

Kučinskaite, J.; Putelyte, G. 2007. Which bank is the best? Veidas 47: 18-21.

Opricovic, S.; Tzeng, G. H. 2004. Compromise solution by MCDM methods: A comparative analysis of VIKOR and TOPSIS, European Journal of Operational Research 156: 445-455.

Podvezko, V. 2006. Multicriteria evaluation under uncertainty, Business: Theory and Practice 7(2): 81-88.

Podvezko, V. 2007. Determining the level of agreement of expert estimates, International Journal of Management and Decision Making 8(5/6): 586-600.

Putelytė, G. 2004. Indèliai nebepasiveja paskolų, Veidas 35:16-17.

Saaty, T. L. 1980. The Analytic Hierarchy Process. New York: M. Graw-Hill.

Saaty, T. L. 2005. The analytic hierarchy and analytic network processes for the measurement of intangible criteria and for decision-making, in Figueira, J.; Greco, S.; Ehrgott,
M. (eds.). Multiple Criteria Decision Analysis: State of the Art Survey. Springer, 9: 345-408.

Shevchenko, G.; Ustinovichius, L.; Andruškevičius, A. 2008. Multi-attribute analysis of investments risk alternatives in construction, Technological and Economic Development of Economy 14(3): 428-443.

Su, Ch.W.; Cheng, M.Y.; Lin, F.B. 2006. Simulation-enhanced approach for ranking major transport projects, Journal of Civil Engineering and Management 12(4): 285-291.

Turskis, Z.; Zavadskas, E. K.; Zagorskas, J. 2006. Sustainable city compactness evaluation on the basis of GIS and Bayes rule, International Journal of Strategic Property Management 10 (3): 185-207.

Ustinovichius, L.; Zavadskas, E. K. 2004. Determining the effectiveness of construction investments by multicriteria methods. Vilnius: Technika.

Ustinovichius, L.; Zavadskas, E. K.; Podvezko, V. 2007. Application of a quantitative multiple criteria decision making (MCDM-1) approach to the analysis of investments in construction, Control and Cybernetics 35(2): 251-268.

Viteikienè, M. 2006. Sustainable residential areas evaluation, Technological and Economic Development of Economy 12(2): 152-160.

Viteikiene, M; Zavadskas, E. K. 2007. Evaluating the sustainability of Vilnius city residential areas, Journal of Civil Engineering and Management 13(2): 149-155.

Zavadskas, E. K.; Kaklauskas, A. 2007. Mehrzielselektion für Entscheidungen im Bauwesen, [Multi-attribute Decisions in Construction], Fraunhofer IRB Verlag (In German).

Zavadskas, E. K.; Kaklauskas, A.; Peldschus, F.; Turskis, Z. 2007. Multi-attribute assessment of road design solution by using the COPRAS method, The Baltic Journal of Road and Bridge Engineering 2(4): 195-203.

Zavadskas, E. K.; Zakarevicius, A.; Antucheviciene, J. 2006. Evaluation of Ranking Accuracy in Multi-Criteria Decisions, Informatica 17(4): 601-618.

Zavadskas, E. K.; Antucheviciene, J. 2007. Multiple criteria evaluation of rural buildings' regeneration alternatives, Building and Environment 42(1): 436-451. 